The change of command at Columbia should silence anybody who believes that students have power only to make noise. Dr Grayson Kirk, the retiring president, was forced to resign simply because the students did not like him. He himself appeared not to realize this when he called in the police force of New York City to throw the students out of the university buildings which they had occupied last spring. The police responded to the call with a gusto which cost Dr Kirk his job. The teaching staff, which until then had tended to be critical of the students' revolt and its irrelevant insistence that the university should not build a gymnasium overlooking the slums of Harlem, swiftly turned against their boss. Dr Kirk had to go and conceded as much when he announced his retirement, a year ahead of plan, in the interests of "more normal university operations during the coming academic year".

The sad fact is, however, that Dr Kirk has critics who feel that he did something much worse for the health of his university than to call in the police to throw out students who had, after all, invaded his office and vandalized his personal papers. In the hope of vast revenues, he committed the university to an uneasy liaison with an unproven cigarette filter without consulting the distinguished men at Columbia's medical school-and made the news public at a hasty press conference which caught the faculty as much by surprise as it did the New York Stock Exchange. That arrangement was quietly dropped several months later.

Columbia, like most of America's large private universities, is desperately in need of new sources of funds, and Dr Kirk, to his credit, had raised about half the $\$ 200$ million goal set in the current fund drive. $(\mathrm{He}$ will continue to run the drive in his new post of president emeritus.) Meanwhile, speculation is buzzing over the possibilities for Mr Cordier's successor. Senator Eugene McCarthy has been named as one who might prefer to be president of a university rather than president of his country. As the search goes on, it is interesting to ask people outside Columbia if they can remember who held the job before Dr Kirk. took over in 1953. (The answer, as at least Senator McCarthy will remember, is General Dwight Eisenhower.)

\section{RESEARCH COUNCILS}

\section{Developing the Environment}

REORGANIZATION and development are once again the themes of the annual report of the Natural Environment Research Council, now three years old (HMSO, $12 s .6 d$.$) . Plans for future research in geology and geo-$ physics are now largely complete, and the provision of new premises seems to be all that is required to implement them.

Within the Institute of Geological Sciences, the Geological Survey of Great Britain will maintain its present importance, but other projects are being developed. The mineral resources division has expanded to include a mineral assessment unit to survey reserves of useful minerals at home and abroad. There is also to be more emphasis on geochemistry, and a new division devoted to this subject has been set up from the former atomic division, the age determination group and parts of the mineral resources division. A small unit is also planned to carry out applied geochemical work in the field.

The marine sciences have been another important field of activity during the past year. New plans have resulted from a survey carried out by the council in participation with an interdepartmental committee of present and future plans and their justification. There is to be more emphasis on inshore environment, which is in urgent need of more intensive research in view of the consequences of human activity in this part of the sea.

The Plymouth Laboratory of the Marine Biological Association, which is already engaged in research into pollution, is now overcrowded, and negotiations with Plymouth Corporation are in progress concerning a site for a new building. The new laboratory of the Scottish Marine Biological Association at Oban, which is progressing well, will house a project concerned with finding effective methods of fish farming. A survey of suitable locks for growing fish is already in progress. The laboratory at Millport will eventually lose a substantial proportion of its staff to Oban, and the future of Millport is "under consideration".

The newly formed Institute of Hydrology, promoted from the Hydrological Research Unit, will undertake a research project to cost about $£ 200,000$ to collect and analyse existing data concerned with the occurrence of floods in the United Kingdom. This is just part of the increased interest that the council intends to take in the development of hydrology. This subject is also to be encouraged in the universities, and this year the council has given $£ 100,698$ in research grants for hydrological research. The largest of these grants is $£ 76,000$ to $\mathrm{Mr}$ T. O'Donell of Imperial College for a study of the hydrology of laboratory catchments.

\section{LEARNED SOCIETIES \\ European Federation}

THe European Physical Society will almost certainly come formally into existence next Thursday (September 26) at Geneva, when a meeting of delegates from various physical societies throughout Europe will put what it is hoped will be the finishing touches to the constitution and elect an executive committee to carry on the business of the European society until it makes its first claim on public attention at a conference in Florence on April 11 next year. The biggest uncertainty remaining is the extent to which the new society, which is constitutionally a federation, will include representatives from Eastern Europe. Discussions have so far involved delegations from most countries in the east and from the Soviet Union as well, and there has been a plan for opening an office in Prague to complement that to be established in Geneva and, at the same time, to get round the problem of exporting cash from the Warsaw countries.

The constitution of the new federation has few terrors for the meeting next week. The council of forty members will eventually be nominated by the member societies, none of which may have more than five representatives. Day to day business will be the responsibility of a smaller executive committee, eventually to be appointed by the council. Provision has been made for individual membership, largely because 